DOI.

https://doi.org/10.22219/fths.v2i1

Received: November 2018

Accepted: Desember 2018

Available online: Februari 2019

\title{
Karakteristik Fisik Kimia Kitosan Dari Cangkang Rajungan (Portunus pelagius) Melalui Proses Deasetilasi Dengan Konsentrasi NaOH dan Waktu Ekstraksi Serta Di Aplikasikan Sebagai Bahan Pengawet Alami Pada Fillet Ikan Nila
}

\author{
Izzah Nazilatul laili ${ }^{1}$, Noor Harini ${ }^{1 *}$, Sukardi ${ }^{1}$ \\ ${ }^{1}$ Program Studi Ilmu dan Teknologi Pangan, Fakultas Pertanian Peternakan Universitas \\ Muhammadiyah Malang, Malang, Indonesia \\ *Corresponding author email : harini@umm.ac.id
}

\begin{abstract}
This research is done by 2 stages of making chitosan and applying on tilapia fish fillet. Objectives at stage 1 to determine the optimization of the difference in $\mathrm{NaOH}$ concentration (20\%, 30\%, 40\% and 50\%) and time (30 minutes and 45 minutes) deacetylation extraction. while the objective at stage 2 to find out the effect nof difference of chitosan addition to natural preservative of tilapia fillet $(0.5 \%, 1 \%, 1.5 \%$ and $2 \%)$. Chitosan tests were performed on physicochemical properties (moisture content, ash content, protein content, solubility, viscosity, yield and deacetylation degree) and fish fillet test (organoleptic and total plate count (TPC). The results showed that different concentrations of $\mathrm{NaOH}$ and extraction time deacetylation very significant effect on ash content, protein content, viscosity, solubility, degree of deacetylation and yield. While the concentration of chitosan is applied to meat Tilapia fish fillet very significant effect on the preservation of the storage period. The best treatment at stage 1 is K3A2.
\end{abstract}

Keyword: Chitosan, Crab waste, Deacetylation, Food preservative, Tilapia fish fillet

\section{PENDAHULUAN}

Potensi perairan di Indonesia kaya akan berbagai jenis invertebrata misalnya rajungan. Indonesia merupakan negara yang mengekspor hasil perikanan dalam jumlah banyak ke Asia maupun luar Asia. Setiap tahun, menurut catatan Departemen Kelautan dan Perikanan tahun (2000), cold storage (perusahaan pengolahan ikan) tanah air menghasilkan limbah cangkang rajungan tidak kurang dari 56.200 ton. Semakin meningkatnya permintaan ekspor berdampak banyaknya volume limbah yang dihasilkan. Salah satu alternatif untuk memanfaatkan limbah dari hasil pengolahan rajungan agar memiliki nilai ekonomis tinggi dan nilai guna adalah mengolahnya menjadi kitin dan kitosan.

Ikan merupakan bahan pangan yang tergolong mudah mengalami kerusakan. Hal ini menunjukkan perlu adanya tindakan untuk memperpanjang 
masa simpan fillet ikan dalam rantai penjualan, salah satunya yaitu dengan penambahan bahan pengawet. Proses pembuatan kitosan untuk mendapatkan kualitas yang baik maka perlu dilakukan adanya modifkasi dalam pembuatannya. Perlakuan proses ekstraksi deasetilasi dengan memodifikasi konsentrasi $\mathrm{NaOH}$ dan waktu dapat meningkatkan kelarutan dan derajat deasetilasi kitosan sebagai pengawet. Kitosan diaplikasikan pada bahan makanan dengan cara pelapisan (coating) (Harianingsih, 2010).

Tujuan dari penelitian ini adalah Mengetahui pengaruh konsentrasi $\mathrm{NaOH}$ yang berbeda saat proses deasetilasi pada karakteristik kitosan cangkang rajungan. Kemudia untuk mengetahui waktu yang optimal untuk ekstraksi deasetilasi yang berbeda pada karakteristik kitosan cangkang rajungan. Selain itu unutk mengetahui pengaruh penambahan edible coating kitosan untuk pengawet alami fillet ikan Nila terhadap periode penyimpanan.

\section{METODE PENELITIAN}

Bahan

Bahan yang digunakan dalam penelitian ini adalah cangkang rajungan (portunus pelagicus) yang diperoleh dari Mini Plan Grand Pelangi Tongas Probolinggo.

Alat

Alat yang digunakan untuk analisis adalah labu kjeldahl, lemari asam, desikator, spektroakopi UV.

\section{Ekstraksi Kitin}

Tahapan ini memodifikasi perlakuan ekstraksi deasetilasi kitin dalam pembuatan kitosan. Penelitian ini terdiri dari preparasi bahan baku dan ekstraksi kitosan yang mengacu pada penelitian Tanasae, et al., (2006).

\section{Aplikasi Kitin pada fillet ikan Nila}

Tahap aplikasi dilakukan percobaan perendaman fillet ikan Nila dalam variasi konsentrasi jumlah kitosan di $100 \mathrm{ml}$ larutan asam asetat $1 \%$. Penelitian ini terdiri dari pembuatan larutan kitosan dan proses perendaman fillet ikan Nila dalam larutan.

\section{Parameter Penelitian}

Parameter pengamatan yang dilakukan adalah analisa bahan baku (cangkang rajungan) meliputi kadar air, abu dan protein. Sedangkan pada kitosan meliputi kadar air, abu, protein, viskositas, rendemen, kelarutan, derajat deasetilasi dan penampakan mikroskopik untuk perlakuan terbaik. Kemudian untuk fillet ikan Nila hasil aplikasi dengan kitosan diuji total bakteri dan organoleptik (tekstur, aroma, dan kenampakan) akibat disimpan selama 2 hari.

\section{Rancangan Percobaan dan Analisa Data}


Pada tahapan pertama, rancangan yang digunakan adalah Rancangan Acak Kelompok (RAK) faktorial. Faktor perlakuan yang dicobakan terdiri dari 2 macam dan masing-masing perlakuan diulang 3 kali. Faktor yang dicobakan adalah faktor 1 konsentrasi $\mathrm{NaOH}$ (4 level) yaitu 20\%; 30\%; 40\% dan 50\% dan faktor 2 waktu (2 level) yaitu 30 dan 45 menit. Pengaplikasian variasi konsentrasi $\mathrm{NaOH}$ dan waktu pengadukan pada saat proses deasitilisasi. Kitosan perlakuan terbaik tahap 1 selanjutnya diaplikasikan pada fillet ikan Nila. Sedangkan pada tahapan kedua digunakan Rancagan Acak kelompok (RAK) sederhana dengan 1 faktor, dimana faktor 1 adalah perbedaan konsentrasi penambahan kitosan yang dilarutkan dalam $100 \mathrm{ml}$ asam asetat $1 \%$ serta periode waktu penyimpanan 0 hari, 1 hari dan 2 hari. Kemudian diulang sebanyak 5 kali ulangan. Perlakuan yang dicobakan adalah variasi konsentrasi jumlah kitosan dalam $100 \mathrm{ml}$ asam asetat $1 \%$ terdiri 5 level yaitu $0 \mathrm{~g} ; 0,5 \mathrm{~g} ; 1 \mathrm{~g}$; $1,5 \mathrm{~g}$ dan $2 \mathrm{~g}$.

Pengolahan data dilakukan dengan menggunakan analisis ragam pada taraf $5 \%$ dan $1 \%$. Selanjutnya bila terjadi beda nyata atau interaksi pada masing-masing perlakuan maka data yang sudah diperoleh akan dilanjutkan dengan uji pembeda menggunakan uji DMRT (Duncan's Multiple Range Test) pada taraf $5 \%$, dan $1 \%$.

\section{HASIL DAN PEMBAHASAN}

Analisis Bahan Baku Cangkang Rajungan

bahan baku. Berikut ini disajikan hasil analisa bahan baku dengan literatur pada Tabel 1.

Tabel 1. Komposisi kimia tepung rajungan (bahan baku)

\begin{tabular}{ccc}
\hline Parameter & Tepung rajungan (\%) & Literatur (\%) \\
\hline Kadar Air & $4,94^{\mathrm{a}}$ & 4,32 \\
Kadar abu & $45,66^{\mathrm{b}}$ & 46,28 \\
Kadar protein & $30,73^{\mathrm{b}}$ & 34,18 \\
\hline
\end{tabular}

Kandungan kimia ketiga komponen pada uji laboratorium mempunyai kisaran data mendekati dengan literatur. Kadar air uji laboratorium $(4,94 \%)$ lebih tinggi dari pada literatur (4,32). Bahwa menurut Estiasih (2009) luas permukaan dapat menjadi faktor kecepatan perpindahan panas karena semakin kecil ukuran akan memperluas permukaan bahan, air lebih mudah berdifusi dan menyebabkan penurunan jarak yang harus ditempuh oleh panas.

Kadar abu uji laboratorium (45,66\%) lebih tinggi dari pada literatur (46,28\%) Bahwa menurut Mima et al. (1983) dalam Hong et. al. (1997) Parameter meliputi uji fisik, kimia serta mikrobiologis. Analisa tahap 1 yaitu rendemen, kadar air, abu, protein, viskositas, kelarutan dan derajat deasetilasi (DD). 
Analisa tahap 2 yaitu organoleptik (kenampakan, warna, tekstur dan aroma) dan total bakteri dengan metode Total Plate Count (TPC).

Cangkang rajungan yang sudah dilakukan proses pengeringan dan penghancuran kemudian menjadi tepung rajungan. Tepung rajungan sebelum diproses menjadi kitosan dilakukan analisa menyatakan bahwa cangkang rajungan memiliki kandungan abu yang sangat tinggi, hal ini dikarenakan komposisi bahan penyusunnya yang memang memiliki kadar abu atau mineral yang tinggi.

Kadar protein uji laboratorium (30,73\%) lebih tinggi dari pada literatur (34,18\%). Menurut Multazam (2002) besarnya kandungan protein pada cangkang rajungan dikarenakan peranannya sebagai pembentukan pigmen, sehingga kandungan proteinya pun cukup tinggi.

\section{Kadar Air dan Viskositas Kitosan}

Kandungan air dan viskositas merupakan parameter yang dapat memberikan informasi terhadap tingkat kemurnian kitosan. Data kadar air dan viskositas terhadap perlakuan lama waktu ekstraksi tercantum pada Gambar 1.

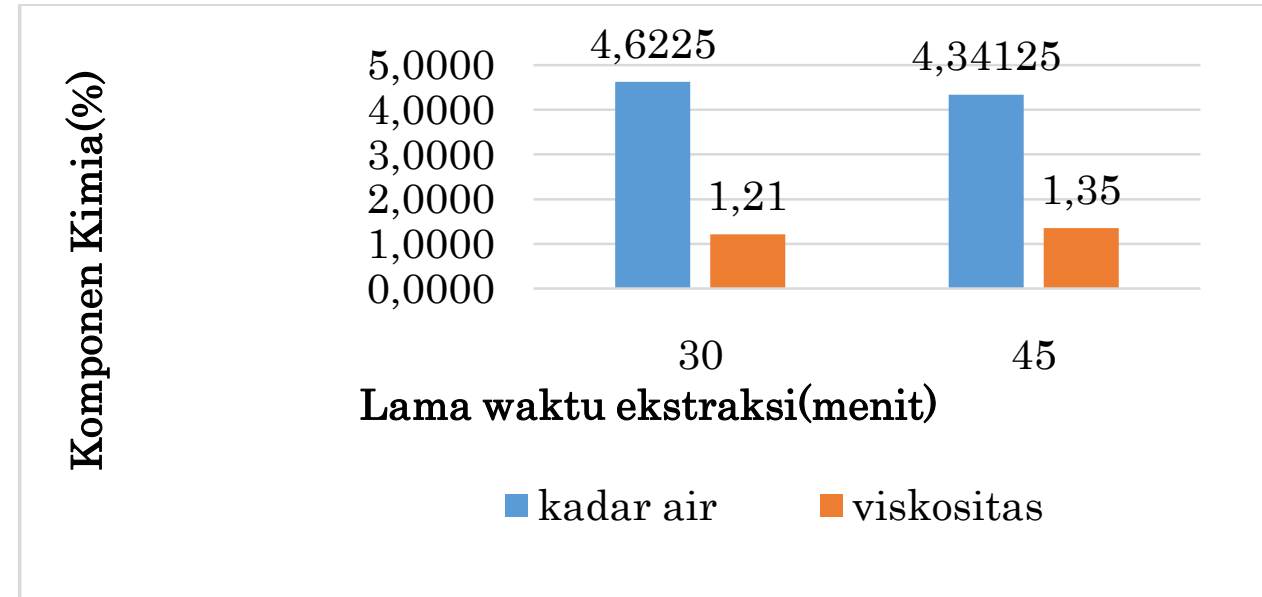

Gambar 1. Rerata Kadar Air dan viskositas Kitosan Akibat Variasi Waktu Ekstrasi

Data kadar air dengan perlakuan variasi konsentrasi $\mathrm{NaOH}$ tercantum pada Gambar 2. 


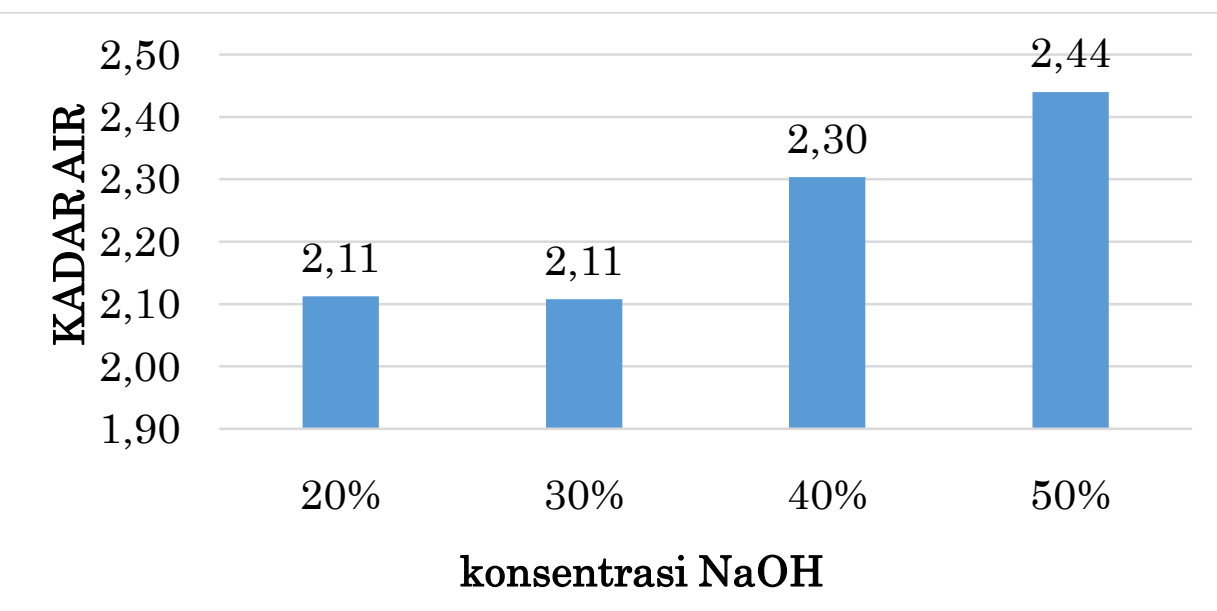

Gambar 2. Rerata Kadar Air Kitosan Akibat Variasi Konsentrasi $\mathrm{NaOH}$

Hasil analisis ragam menunjukkan bahwa tidak terjadi interaksi yang nyata antara perlakuan perbedaan konsentrasi $\mathrm{NaOH}$ dan waktu terhadap kadar air pada kitosan. Menurut Sophanodora dan Benjakula (1993) diacu dalam Fauzan (2001) bahwa kadar air kitosan tidak dipengaruhi oleh jumlah bahan, nisbah dan waktu proses akan tetapi pada proses pengeringan terhadap kitosan yang dihasilkan. Hasil analisa ragam menunjukkan bahwa terjadi interaksi yang sangat nyata pada perlakuan variasi konsentrasi $\mathrm{NaOH}$ terhadap viskositas kitosan.

Tabel 2. Rerata Viskositas Kitosan Cangkang Rajungan Akibat Variasi Konsentrasi $\mathrm{NaOH}$

\begin{tabular}{llc}
\hline & Perlakuan & Viskositas (d.P.as) \\
\hline K0 (NaOH 20\%) & NaOH $20 \%$ & $0,21 \mathrm{a}$ \\
$\mathrm{K} 1(\mathrm{NaOH} 30 \%)$ & $\mathrm{NaOH} \mathrm{30 \%}$ & $0,24 \mathrm{a}$ \\
$\mathrm{K} 2(\mathrm{NaOH} \mathrm{40 \% )}$ & $\mathrm{NaOH} \mathrm{40 \%}$ & $0,38 \mathrm{ab}$ \\
$\mathrm{K} 3(\mathrm{NaOH} \mathrm{50 \% )}$ & $\mathrm{NaOH} \mathrm{50 \%}$ & $0,44 \mathrm{~b}$ \\
\hline
\end{tabular}

Keterangan : Nilai rerata yang diikuti oleh huruf yang sama tidak berbeda nyata menurut uji Duncan's $\alpha=5 \%$.

Viskositas kitosan cangkang rajungan berada pada kisaran 1,21-1,35. Menurut Kurniasih (2011) bahwa perbedaan viskositas berakibat pada tingkat toleransi terhadap kadar abu, semakin tinggi nilai rerata viskositas maka nilai rerata kadar abu semakin menurun.

\section{Kadar Abu dan Protein Kitosan}


Kandungan abu dan protein kitosan turut memberikan informasi terkait keadaan kemurnian kitosan. Data kadar abu dan protein kitosan dapat dilihat pada Tabel 3 .

Tabel 3. Rerata Rendemen, Kelarutan dan DD Kitosan Cangkang Rajungan Akibat Variasi Konsentrasi $\mathrm{NaOH}$ dan Waktu Ekstraksi

\begin{tabular}{ccc}
\hline Level Perlakuan & Kadar Abu (\%) & Kadar Protein (\%) \\
\hline K0A1 (NaOH 20\%;30meit) & $0,42^{\mathrm{e}}$ & $11,50^{\mathrm{cd}}$ \\
$\mathrm{K} 1 \mathrm{~A} 1$ (NaOH 30\%;30meit) & $0,38^{\mathrm{d}}$ & $10,57^{\mathrm{cd}}$ \\
$\mathrm{K} 2 \mathrm{~A} 1$ (NaOH 40\%;30meit) & $0,31^{\mathrm{b}}$ & $9,81^{\mathrm{bc}}$ \\
$\mathrm{K} 3 \mathrm{~A} 1$ (NaOH 50\%;30meit) & $0,31^{\mathrm{b}}$ & $9,26^{\mathrm{c}}$ \\
$\mathrm{K} 0 \mathrm{~A} 2$ (NaOH 20\%;45meit) & $0,34^{\mathrm{c}}$ & $11,34^{\mathrm{cd}}$ \\
$\mathrm{K} 1 \mathrm{~A} 2$ (NaOH 30\%;45meit) & $0,35^{\mathrm{cd}}$ & $10,36^{\mathrm{c}}$ \\
$\mathrm{K} 2 \mathrm{~A} 2$ (NaOH 40\%;45meit) & $0,33^{\mathrm{bc}}$ & $9,13^{\mathrm{b}}$ \\
$\mathrm{K} 3 \mathrm{~A} 2$ (NaOH 50\%;45meit) & $0,27^{\mathrm{a}}$ & $7,62^{\mathrm{a}}$ \\
\hline
\end{tabular}

Keterangan : Nilai rerata yang diikuti oleh huruf yang sama tidak berbeda nyata menurut uji Duncan's a $=5 \%$.

Semakin rendah nilai kadar abu kitosan, tingkat efektifitas proses demineralisasi semakin tinggi. Bahwa menurut Karmas (1982) proses demineralisasi akan berlangsung sempurna dengan mengusahakan agar konsentrasi asam yang digunakan serendah mungkin dan disertai dengan pengadukan yang konstan.

Konsentrasi $\mathrm{NaOH}$ mempengaruhi kandungan protein kitosan bahwa menurut. Menurut Benjakula dan Sophanodora (1993) bahwa kadar total nitrogen berupa protein yang dapat dihilangkan sangat dipengaruhi oleh konsentrasi $\mathrm{NaOH}$ dan waktu ekstraksi. Proses pengadukan yang konstan merupakan faktor yang mempermudah penghilangan protein dari cangkang rajungan melalui reaksi antara larutan $\mathrm{NaOH}$ dengan bahan.

\section{Rendemen,Kelarutan dan Derajat Deasetilasi Kitosan}

Kelarutan dan derajat deasetilasi adalah parameter saling berhubungan untuk menentukan mutu dari kitosan. Data rendemen, kelarutan dan derajat deasetilasi Kitosan dapat dilihat sebagai berikut:

Tabel 4. Rerata Rendemen, Kelarutan dan Derajat Deasetilasi Kitosan Cangkang Rajungan Akibat Variasi Konsentrasi $\mathrm{NaOH}$ dan Waktu Ekstraksi. 


\begin{tabular}{cccc}
\hline Level Perlakuan & $\begin{array}{c}\text { Rendemen } \\
(\%)\end{array}$ & Kelarutan (\%) & $\begin{array}{c}\text { Derajat } \\
\text { deasetilasi (\%) }\end{array}$ \\
\hline K0A1 (NaOH 20\%:30meit) & $35,77 \mathrm{e}$ & $72,97 \mathrm{a}$ & $70,95 \mathrm{a}$ \\
K1A1 (NaOH 30\%:30meit) & $30,67 \mathrm{c}$ & $81,68 \mathrm{~b}$ & $88,63 \mathrm{c}$ \\
K2A1 (NaOH 40\%:30meit) & $21,81 \mathrm{a}$ & $85,06 \mathrm{c}$ & $89,09 \mathrm{c}$ \\
K3A1 (NaOH 50\%:30meit) & $21,54 \mathrm{a}$ & $90,47 \mathrm{~d}$ & $98,18 \mathrm{~d}$ \\
K0A2 (NaOH 20\%:45meit) & $34,27 \mathrm{~d}$ & $81,98 \mathrm{~b}$ & $81,02 \mathrm{~b}$ \\
K1A2 (NaOH 30\%:45meit) & $30,19 \mathrm{c}$ & $91,11 \mathrm{~d}$ & $88,03 \mathrm{c}$ \\
K2A2 (NaOH 40\%:45meit) & $25,00 \mathrm{~b}$ & $93,17 \mathrm{de}$ & $89,50 \mathrm{c}$ \\
K3A2 (NaOH 50\%:45meit) & $21,49 \mathrm{a}$ & $93,61 \mathrm{e}$ & $98,24 \mathrm{~d}$ \\
\hline
\end{tabular}

Keterangan : Nilai rerata yang diikuti oleh huruf yang sama tidak berbeda nyata menurut uji Duncan's $\alpha=5 \%$.

Hasil analisis ragam menunjukkan bahwa terjadi interaksi yang sangat nyata antara perlakuan variasi konsentrasi $\mathrm{NaOH}$ dan waktu ekstraksi terhadap rendemen kitosan. Menurut Muzarelli diacu dalam Bastaman (1989) menyatakan bahwa rendemen kitosan menurun sejalan dengan meningkatknya konsentrasi $\mathrm{NaOH}$ dan waktu pada saat proses ekstraksi deasetilasi.

Hasil analisa ragam menunjukkan bahwa terjadi interaksi yang sangat nyata antara variasi konsentrasi $\mathrm{NaOH}$ dan waktu ekstraksi terhadap kelarutan kitosan. Hal ini disebabkan peningkatan kelarutan kitosan yang dihasilkan berbanding lurus dengan semakin meningkatnya nilai derajat deasetilasi (Rochima, 2005)

Derajat deasetilasi merupakan faktor penting dalam karakteristik kitosan. Hasil analisa ragam menunjukkan bahwa terjadi interaksi yang sangat nyata antara variasi konsentrasi $\mathrm{NaOH}$ dan waktu ekstraksi terhadap derajat deasetilasi kitosan. Hal ini sesuai dengan pernyataan Rochima (2005) nilai derajat deasetilasi yang semakin meningkat disebabkan gugus asetil. Ion $\mathrm{H}+$ pada gugus amina menjadikan kitosan mudah berinteraksi dengan air melalui ikatan hidrogen.

\section{Perlakuan Terbaik Tahap 1}

Berdasarkan analisis De Garmo perlakuan terbaik pada pembuatan kitosan dengan konsentrasi $\mathrm{NaOH}$ dan waktu yang berbeda-beda didapatkan pada perlakuan K3A2 dengan konsentrasi $\mathrm{NaOH} 50 \%$ dan waktu ekstrasi 45 menit. Variasi konsentrasi $\mathrm{NaOH}$ dan waktu ekstraksi memberikan pengaruh pada komponen kimiawi bahan baku cangkang rajungan. Pemanasan dengan suhu $\left(100^{\circ} \mathrm{C}\right)$ mengakibatkan kandungan mineral (abu) dan protein mengalami perubahan stabilitas sehingga mengalami penurunan kadar abu dan denaturasi protein. Akibat hal tersebut, maka proses demineralisasi, deproteinasi dan deasetilasi optimal. 


\section{Penampakan Mikroskopis Kitosan}

Analisa mikroskopis kitosan dilakukan menggunakan mikroskop yang bertujuan untuk mengetahui ukuran partikel pada kitosan. Ukuran pada kitosan mempengaruhi daya larut sebagai bahan pengawet. Dapat dilihat sebagai berikut:

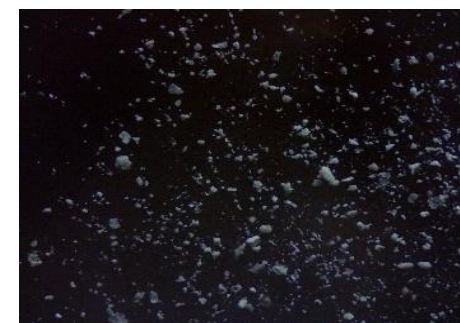

(a)

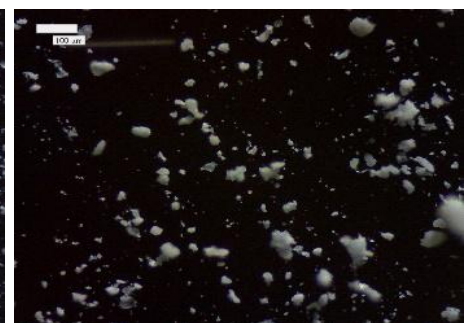

(b)

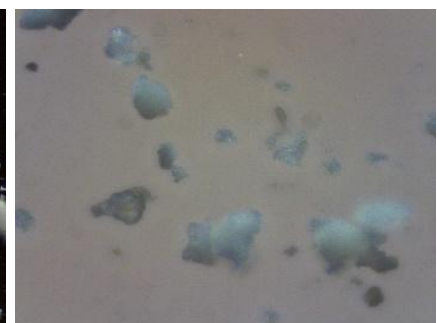

(c)

Gambar 3. Gambar Mikroskopik Kitosan Variasi Konsentrasi NaOH 20\%:Waktu Ekstraksi 30 menit 40X(a), 100X(b) dan 400X (c)

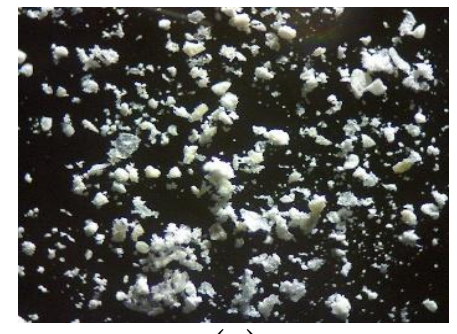

(a)

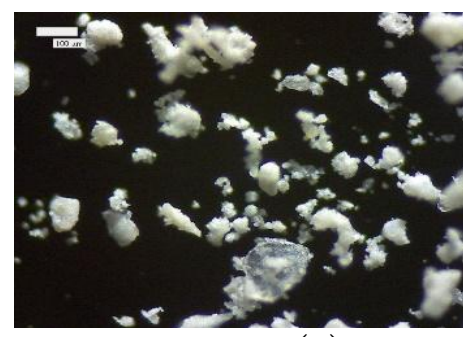

(b)

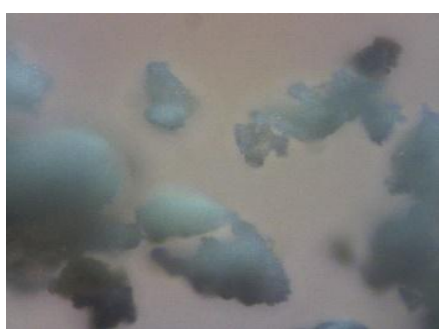

(c)

Gambar 4. Gambar Mikroskopik Kitosan Variasi Konsentrasi NaOH 50\%:Waktu Ekstraksi 45 menit 40X(a), 100X(b) dan 400X (c)

Perlakuan terbaik K3A2 (NaOH 50\%:45 menit) menyebabkan ukuran kitosan semakin kecil dengan bertambahnya konsentrasi $\mathrm{NaOH}$ dan lama nya waktu ekstraksi. Menurut Johnson (1982) semakin lama waktu ekstraksi akan menyebabkan pecahnya ikatan polimer (depolimerisasi) rantai molekul sehingga menurunkan berat molekul kitosan. Sedangkan pada perlakuan terjelek K0A1 ( $\mathrm{NaOH}$ 20\%:30 menit) memiliki ukuran yang tidak seragam disebabkan pada proses ekstraksi menggunakan waktu yang singkat sehingga rantai molekul tidak terpecah sempurna.

\section{Aplikasi Perlakuan Terbaik Kitosan Cangkang Rajungan terhadap Umur Simpan Fillet Ikan Nila Organoleptik Fillet Ikan Nila}

Penilaian secara organoleptik panelis merupakan penilaian secara mutu produk secara visual. Organoleptik meliputi kanampakan, warna, tekstur dan aroma fillet ikan Nila yang diamati secara berkala seperti tersaji pada Gambar 5. Data skor organoleptic fillet ikan Nila akibat variasi konsentrasi kitosan dapat dilihat pada Gambar 5. 


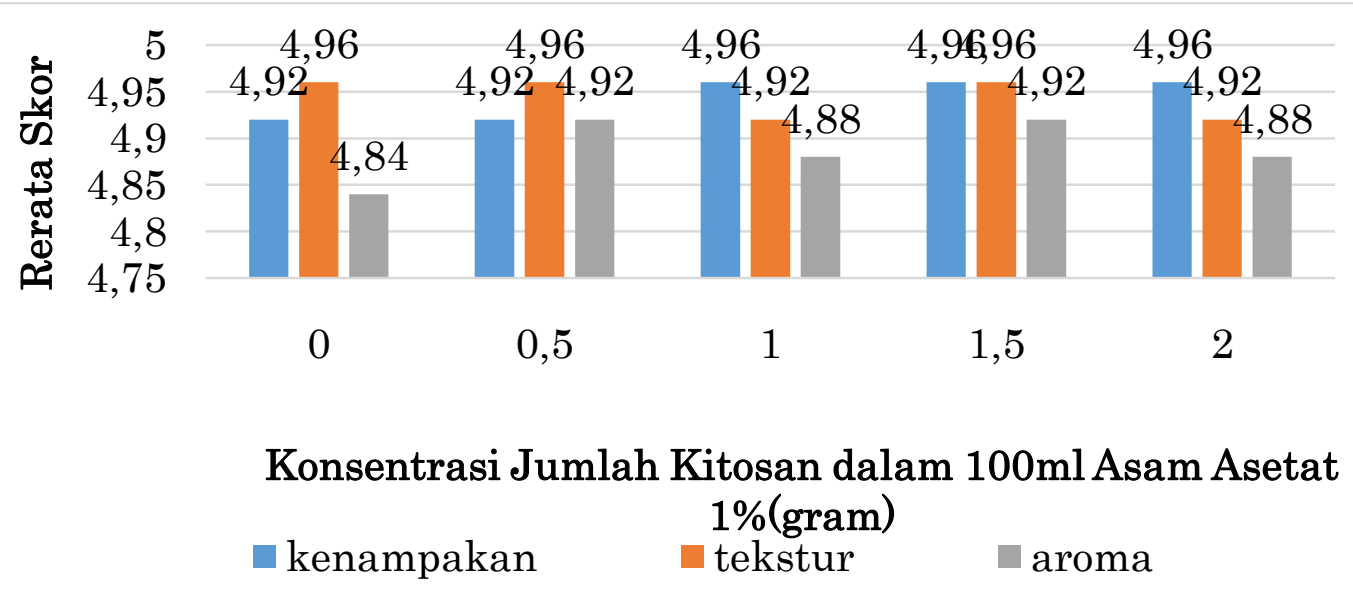

Gambar 5. Rerata Skor Organoleptik Fillet Ikan Nila Akibat Variasi Konsentrasi Kitosan dama 100ml Asam Asetat 1\% Penyimpanan Hari ke-0

Keempat organoleptik ini merupakan parameter untuk menentukan mutu dari segi fisik pada fillet ikan Nila. Pada penyimpanan hari ke-0 masih terlihat sama semua dari beberapa parameter. Dimana fillet ikan Nila memiliki aroma yang khas bau ikan, kenampakan dan tekstur yang masih baik. Penilaian organoleptik fillet ikan Nila akibat variasi konsentrasi kitosan penyimpanan hari 1 dan 2 tercantum pada Tabel 5 .

Pada hari penyimpanan ke-1 dan 2 kenampakan fillet ikan Nila tanpa perlakuan perendaman menunjukkan tanda kerusakan seperti kenampakannya agak kusam. Berbeda dengan penambahan kitosan kenampakan ikan semakin baik. Sedangkan untuk hari ke-1 dan 2 kenampakan ikan semakin jelek pada perlakuan tanpa perendaman kitosan. Menurut Siska et al., (2012) menyatakan bahwa penurunan nilai tersebut terjadi karena adanya perubahan secara fisik, kimiawi dan mikrobiologi.

Tabel 5. Rerata Skor Organoleptic Fillet Ikan Nila Akibat Variasi Konsentrasi Kitoan Dalam 100ml Asam Asetat 1\% Penyimpanan Hari Ke-1 Dan 2

\begin{tabular}{llll}
\hline Perlakuan Kitosan & Kenampakan & Tekstur & Aroma
\end{tabular}




\begin{tabular}{ccccccc} 
(dalam 100ml Asam & Hari ke- & Hari ke- & Hari ke- & Hari \\
Asetat 1\%) & 1 & 2 & 1 & ke-2 & $\begin{array}{c}\text { Hari ke- } \\
1\end{array}$ & $\begin{array}{c}\text { Hari ke- } \\
2\end{array}$ \\
\hline 0 (0 gram) & $2,68 \mathrm{a}$ & $1,00 \mathrm{a}$ & $2,44 \mathrm{a}$ & $1,00 \mathrm{a}$ & $2,56 \mathrm{a}$ & $1,00 \mathrm{a}$ \\
$0,5(0,5$ gram$)$ & $3,52 \mathrm{~b}$ & $1,32 \mathrm{a}$ & $2,76 \mathrm{a}$ & $1,28 \mathrm{~b}$ & $3,08 \mathrm{~b}$ & $1,28 \mathrm{~b}$ \\
$1(1$ gram$)$ & $4,2 \mathrm{c}$ & $3,16 \mathrm{~b}$ & $2,54 \mathrm{a}$ & $2,16 \mathrm{c}$ & $3,76 \mathrm{c}$ & $2,16 \mathrm{c}$ \\
$1,5(1,5$ gram $)$ & $4,44 \mathrm{~d}$ & $3,36 \mathrm{~b}$ & $3,72 \mathrm{~b}$ & $3,72 \mathrm{~d}$ & $4,20 \mathrm{~d}$ & $3,72 \mathrm{~d}$ \\
$2(2$ gram $)$ & $4,88 \mathrm{e}$ & $3,84 \mathrm{c}$ & $4,56 \mathrm{c}$ & $4,24 \mathrm{~d}$ & $4,60 \mathrm{e}$ & $4,24 \mathrm{e}$
\end{tabular}

Keterangan: Nilai rerata yang diikuti oleh huruf yang sama tidak berbeda nyata menurut uji Duncan's $\alpha=5 \%$.

Keterangan skor

$\begin{array}{lll}\text { Kenampakan } & \text { Tekstur } & \text { Aroma } \\ \text { 1= Perubahan seluruh permukaan } & \text { 1= lunak } & \text { 1= busuk } \\ \text { 2= Kusam } & \text { 2= tidak elatis } & \text { 2= mengarah busuk } \\ \text { 3= Agak kusam } & \text { 3= kurag elastis } & \text { 3= tidak beraroma } \\ \text { 4= cerah dan kurang mengkilap } & 4=\text { kurang padat } & 4=\text { sedikit segar } \\ \text { 5= cerah dan mengkilap } & 5=\text { kompak, elastis } & 5=\text { segar }\end{array}$

Fillet ikan Nila dengan kitosan 2 gram menunjukkan nilai skor tertinggi tekstur, secara visual daging fillet ikan nila memiliki tekstur yang kompak dan elastis pada penyimpanan hari ke 1 dan 2 . Berbeda dengan tanpa penambahan kitosan yang memiliki tekstur yang kurang elastis dan lunak. Hal ini sesuai dengan penelitian Gustini et al (2014) bahwa tekstur ikan dilapisi dengan larutan kitosan 1\% mengalami kenaikan nilai organoleptik yang lebih tinggi.

Aroma fillet ikan Nila menurun tanpa penambahan kitosan, dapat dilihat pada Tabel 5 bahwa penyimpanan hari ke 1 dan 2 aroma fillet ikan Nila tidak beraroma dan busuk. Penyimpanan hari ke 1 dan 2 fillet ikan Nila memiliki aroma yang agak segar, bahwa kitosan tidak dapat digunakan untuk mencegah aroma yang tidak diinginkan tetapi fungsi kitosan hanya sebagai pengawet.

\section{Analisis Total Bakteri (Total Plate Count Analysis)}

Kitosan mempunyai manfaat sebagai antibakteri dimana kitosan tersebut memiliki sifat yang dimilikinya yaitu kemampuannya dalam menghambat pertumbuhan mikroorganisme dan kemampuannya dalam memberikan pelapisan/coating terhadap produk sehingga meminimalkan interaksi antara produk dengan lingkungannya. Data TPC fillet ikan Nila akibat variasi konsentrasi kitosan dapat dilihat pada Tabel 6. 
Tabel 6. Rerata TPC fillet ikan Nila dengan perbedaan konsentrasi kitosan dan periode penyimpanan

\begin{tabular}{lccccc}
\hline & \multirow{2}{*}{ Perlakuan } & \multicolumn{3}{c}{ TPC (CFU/gram) } & \multirow{2}{*}{ \% kenaikan } \\
\cline { 3 - 5 } & & Hari ke-0 & Hari ke-1 & Hari ke-2 & \\
\hline N1 & Kontrol & $1,2 \times 10^{-6} \mathrm{e}$ & $2,3 \times 10^{-6} \mathrm{e}$ & $6,9 \times 10^{-6} \mathrm{e}$ & $5,8 \times 10^{-6}$ \\
N2 & Kitosan 0,5\% & $6,6 \times 10^{-5} \mathrm{~d}$ & $2,0 \times 10^{-6} \mathrm{~d}$ & $2,4 \times 10^{-6} \mathrm{~d}$ & $1,06 \times 10^{-6}$ \\
N3 & Kitosan 1\% & $5,3 \times 10^{-5} \mathrm{c}$ & $1,4 \times 10^{-6} \mathrm{c}$ & $1,9 \times 10^{-6} \mathrm{c}$ & $1,03 \times 10^{-6}$ \\
N4 & Kitosan 1,5\% & $4,2 \times 10^{-5} \mathrm{~b}$ & $1,3 \times 10^{-6} \mathrm{~b}$ & $1,6 \times 10^{-6} \mathrm{~b}$ & $7,2 \times 10^{-5}$ \\
N5 & Kitosan 2\% & $3,1 \times 10^{-5} \mathrm{a}$ & $1,1 \times 10^{-6} \mathrm{a}$ & $1,2 \times 10^{-6} \mathrm{a}$ & $4,1 \times 10^{-5}$ \\
\hline
\end{tabular}

Keterangan : Nilai rerata yang diikuti oleh huruf yang sama tidak berbeda nyata menurut uji Duncan's $\alpha=5 \%$.

Menurut uji anova, total jumlah mikroba pada fillet ikan Nila menurun seiring dengan peningkatan konsentrasi kitosan yang ditambahkan. Menurut Xheng dan Zhu (2003), kitosan merupakan polikationik amina akan berinteraksi dengan kutub negatif pada lapisan sel dari bakteri, reduksi dari jumlah sel bakteri dipengaruhi oleh perubahan permukaan sel dan hilangnya fungsi barrier dari bakteri itu sendiri.

\section{Perlakuan Terbaik Tahap II}

Berdasarkan analisis De Garmo, perlakuan terbaik pada penyimpanan hari ke 0 terdapat pada perlakuan N4 (konsentrasi kitosan 1,5\%), dengan nilai

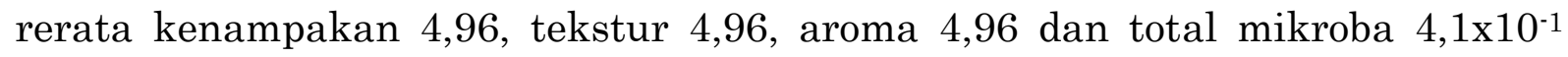
CFU/gram. Sedangkan periode penyimpanan hari ke 1 dan ke 2 perlakuan terbaik terdapat pada perlakuan N4 (konsentrasi kitosan 1,5\%), dengan hasil pada pengamatan hari ke 1 yaitu kenampakan 4,44, tekstur 3,72, aroma 4,20 dan total mikroba $1,28 \times 10^{-2}$. Sedangkan pada periode penyimpanan hari ke 2

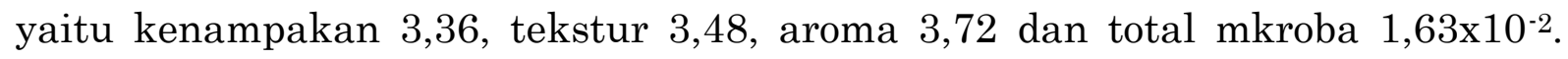
Menurut Kumar (2000), kitosan memiliki sifat yang mudah menyerap air (hidrofilik) yang memungkinkan kitosan untuk dapat menyerap air dari lingkungan, sehingga semakin lama waktu penyimpanan.

\section{KESIMPULAN}

Variasi konsentrasi $\mathrm{NaOH}$ dan waktu ekstraksi dalam tahap modifikasi pembuatan kitosan berpengaruh sangat nyata terhadap kadar abu, protein, rendemen, viskositas, kelarutan, dan derajat deasetilasi. Konsentrasi $\mathrm{NaOH} 50 \%$ dan waktu ekstraksi 45 menit merupakan perlakuan terbaik tahap I. Perlakuan perendaman fillet ikan Nila dengan variasi konsentrasi kitosan berpengaruh sangat nyata terhadap kenampakan, tekstur dan aroma pada penyimpanan hari ke-1 dan 2, sedangkan pada total bakteri berpengaruh sangan nyata pada penyimpanan ke-0, 1 dan 2 . Kitosan 1,5 gram dalam $100 \mathrm{ml}$ larutan asam asetat 


\section{UCAPAN TERIMA KASIH}

Penulis ingin berterimakasih kepada kelola mina laut mini plan grand pelangi-unit tongas probolinggo yang memberikan sumbangan cangkang rajugan.

\section{REFERENSI}

De Garmo, E, P, 1998. Ekonomi Teknik. Erlangga. Jakarta

Departemen Kelautan dan Perikanan. 2000. Statistik Data Perikanan. Jakarta: Departemen Kelautan dan Perikanan.

Estiasih, Teti dan Kgs Ahmadi, 2009. Teknologi Pengolahan Pangan. Bumi Aksara. Malang.

Gustini, Siti K, Ari HY. 2014. Kualitas ikan kembung (Rastrelliger kanagurta) setelah perendaman dalam kitosan ditinjau dari aspek mikrobiologi dan organoleptik. Protobiont 3(2): 100-105.

Harianingsih, 2010. Pemanfaatan Limbah Cangkang Kepiting menjadi Kitosan Sebagai Bahan Pelapis (coater) pada buah Stroberi. Program Magister Teknik Kimia UNDIP : Semarang.

Johnson EL, Peniston QP. 1982. Utilization of shellfish wastes for production of chitin and chitosan. Chemistry and Biochemistry of Marine Food Product. The AVI. Connecticut

Karmas, E., 1982. Poultry and Seafood Technology, Noyes Data Corporation, USA.

Kumar, MNR. 2000. A Review of chitin and chitosan Application. J. Reac and Func Poly. 46: 1-27

Kurniasih, M. 2011. Sintesis dan Karakterisasi Fisika-Kimia Kitosan (Synthesis And Physicochemical Characterization Of Chitosan). Jurnal Inovasi Vol.5 No. 1, Januari 2011: 42-48.

Mima, S., Miya M., Iwamoto R., Yoshikawa, S. 1983. Journal Apllication Polymer dalam Hong, K. N, Samuel P. M. 1989. Preparation of Chitin and Chitosan. Department of Food Science and Technology, Catholic University. Korea Utara.

Bastaman S. 1989. Studies on degradation and extraction of chitin and chitosan from prawn shells [disertation]. Dept Mechanical Manufacturing, Aeronautical and Chemical Engineering. Queen's Univ. Belfast.

Rochima E. 2005. Aplikasi kitin deasetilase termostabil dari Bacillus papandayan K29-14 asal Kawah Kamojang Jawa Barat pada pembuatan kitosan [tesis]. Bogor: Program Pascasarjana, IPB.

Siska J, Mirna I, Desmelati. 2012. Pengaruh penggunaan minuman berkarbonasi untuk menghambat kemunduran mutu ikan gurami (Osphronemus gouramy) pada suhu kamar. Jurnal Perikanan dan Kelautan 17(2): 71-87.

Zheng, Lian Ying dan Zhu, Jiang Feng, 2003. Study on Antimicrobial Activity of Chitosan With Different Molecular Weights. Journal Carbohydrate Polimers, 54(4), 527-530,. 